\title{
Amyloid-beta Interactions with ABC Transporters and Resistance Modifiers
}

\author{
JOSEPH MOLNAR ${ }^{1}$, IMRE OCSOVSZKI ${ }^{2}$ and ROZALIA PUSZTAI ${ }^{1}$ \\ ${ }^{1}$ Department of Medical Microbiology and Immunobiology, \\ ${ }^{2}$ Department of Biochemistry, University of Szeged, Szeged, Hungary
}

\begin{abstract}
Background/Aim: Failure of cancer chemotherapy caused by multidrug resistance (MDR) of tumor cells is mediated by $A B C$ transporters that reduce the uptake of cytotoxic agents. Similar transporters are responsible for amyloid clearance in nerve cells in Alzheimer's disease $(A D)$. The aim of this study was to compare the biological effects of amyloid complexes of some known ABC transporter inhibitors e.g. disiloxanes. One of the most active fragments of the pathological "endogen" substrate responsible for $A D$ was investigated in the presence of amyloid-beta fragment on the reversal of multidrug resistance and apoptosis induction on multidrug-resistant tumor cells in model experiments. Materials and Methods: The efflux pump activity of the cells treated with amyloid-beta complexes was studied by Rhodamin-123 accumulation. Apoptosis induction was measured by staining of treated cells by Annexin- $V$ and propidium iodine. The fluorescent activity FL-1 and FL-2 of the cells was measured and analyzed on a PARTEC FACScan instrument. Results: The resistance modifiers: disiloxanes and memantine complexed with amyloid-beta $1-42$ reduced the activity of ABC transporter in MDR tumor cells. Early apoptosis was moderately increased by amyloid-beta complexes. Late apoptosis and the number of total viable cells were not changed. Conclusion: Amyloid-beta and its complexes inactivate the efflux pump of tumor cells resulting in accumulation of amyloid. It is supposed that reduced membrane transport can explain the lower incidence of cancer in $A D$.
\end{abstract}

This article is freely accessible online.

Correspondence to: Joseph Molnar, Department of Medical Microbiology and Immunobiology, University of Szeged, Szeged, Hungary. Tel: +36 62545114, Fax: +36 62545113, e-mail: molnar.jozsef@med.u-szeged.hu

Key Words: ABC transporter, human MDR1 gene transfected mouse lymphoma cell, amyloid-beta peptide, amyloid-memantine and amyloid-disiloxane complexes, Alzheimer's disease.
The $\mathrm{ABC}$ transporters belong to a functionally heterogeneous group of transporters containing two different groups of ATP-dependent enzymes. The first group is responsible for transport of endogenous substrates e.g. in amyloid-beta transport responsible for the development of AD. The second one participates in the blood brain barrier (BBB) and transport of external substances $e . g$. by exporting toxic chemicals, anticancer drugs from MDR tumor cells. The efflux pump activity of the P-glycoprotein (pgp) in brain capillary endothelial cells and mouse lymphoma cells responsible for MDR were compared in sensitivity to different multidrug resistance modifiers $(1,2)$. In the last few years amyloid-beta "secretion" from the brain cells of patients with $\mathrm{AD}$ was systematically investigated in the presence of various compounds on cultured cells. In a prospective longitudinal study Behreins et al. demonstrated an inverse association between AD and cancer (3). Recently, Dao et al. demonstrated that phenothiazines act as inhibitors of $\beta$-amyloid aggregation and are applied as imaging probes for amyloid plaques in $\mathrm{AD}(4)$.

Our hypothesis was that inhibition of these membrane transporters can be exploited in drug design for treatment of different diseases. The efflux activity of the pgp in MDR tumor cells as a model of the brain capillary endothelium was measured to define interaction between MDR modifiers and amyloid-beta.

In this study the effects of amyloid-beta 1-42 alone and its complexes with resistance modifiers, disiloxans and memantine, were investigated on the activity of MDR efflux pump and on apoptosis induction in mouse lymphoma cells.

\section{Materials and Methods}

Materials. Amyloid-beta 1-42 and memantine were purchased from Sigma (St. Louis, MO, USA) and verapamil from EGIS (Hungarian Pharmaceutical Company, Budapest, Hungary). 12Hbenzo(a) phenothiazine was provided by Motohashi (Tokyo, Japan). Disiloxanes as sila- 409 and sila- 421 were prepared as previously described $(5,6)$.

Cell culture. L5178 mouse T-cell lymphoma cells were transfected with a retrovirus carrying the $M D R$ gene, that codes for pgp, as previously described (6). 
Assay for reversal of MDR in mouse lymphoma cells in the presence of amyloid complexes. The L5178 MDR and L5178Y parent cell lines were grown in McCoy's 5A medium containing $10 \%$ heatinactivated horse serum, L-glutamine and antibiotics. The fluorescence of the cell population was measured with a PARTEC FACScan flow cytometer.

Apoptosis assay. The assay was carried out according to the Protocol of Alexis Biochemicals (Darmstadt, Germany) with minor modifications. The cells were transferred to Eppendorf tubes, centrifuged and resuspended in $1.0 \mathrm{ml}$. Annexin V-FITC was added to the samples. The fluorescent activity (FL-1 and FL-2) of the cells was measured and analyzed on a PARTEC FACScan instrument. The anti-Alzheimer drug memantine was used as a control (7-9).

\section{Results and Discussion}

Membrane transporters in various barriers e.g. BBB, blood placenta barrier, blood retinal barrier, etc. have important roles in maintaining the normal function of cells in the organism. The effectiveness of cancer chemotherapy as in the case for AD therapy, lies in its ability to reach its target(s). This ability is challenged by membrane transporters called pgp or $\mathrm{ABC}$ transporters. These transporters extrude anticancer agents and when over-expressed by suboptimal therapy, render the cancer cell resistant not only to the specific agent, initially employed, but to other anticancer agents as well. Amyloid-beta peptides are implicated in the development of $\mathrm{AD}$ inasmuch as it is the main component of non-soluble amyloid plaques that accumulate intracerebrally (10). Amyloid-beta peptide is chemically "sticky" and gradually builds up into plaques and interferes with nerve transmission signals. As mentioned before, pgp, also known as ABCB1 protein, plays an important and substantial role in the elimination of amyloid from the brain via its activity at the $\mathrm{BBB}$. Relevant to this fact, is the proven ability of this $\mathrm{ABC}$ transporter to extrude amyloid from MDR1 cancer cells (9).

The reversal of the MDR phenotype of cancer cells takes place by inhibition of the $A B C$ transporter that is overexpressed in our model experiments. The effects of MDR modifiers such as disiloxanes sila- 409 and sila-421 alone and memantine complexed with amyloid-beta peptides reduced rhodamine accumulation in the tumor cells. These findings may indicate some new directions for possible drug design to modify amyloid efflux (Table I). Amyloid-beta peptides 1-42 have toxic effects on cells. The complexes formed between amyloid-beta and resistance modifier disiloxanes were not able to increase Rhodamine 123 accumulation in the treated cells despite the fact that the disiloxanes and the positive verapamil control alone significantly inhibited Rhodamine123 efflux from the treated tumor cells resulting in increased intracellular accumulation of rhodamine.

These results demonstrate that amyloid-beta peptides and memantine alone have opposite effects on the $\mathrm{ABC}$ transporter of human MDR1 transfected into mouse cells. In the case of the amyloid-beta peptides 1-42 complexed with the two disiloxanes, the sila-409-amyloid complex reduced rhodamine accumulation, possibly due to direct complex formation with amyloid. In the case of sila-421-amyloid complex, the amyloid was less effective.

The effect of the resistance modifiers alone and their amyloid complexes on apoptosis induction was examined using MDR mouse lymphoma cells (Table II). Small differences were found in the frequency of early apoptosis induction which indicates some non-specific membrane effects. The rate of viable cells was found above 90-95\% percent in the presence of the tested compounds and their complexes with amyloid-beta 1-42. The MDR modifiers verapamil, sila-421, sila-409, and amyloid alone resulted in the reversal of resistance to doxorubicin. Whereas amyloidbeta 1-42 prevented the MDR reversal effect of the resistance modifiers including memantine, sila- 409 and sila421. The compounds studied showed an early apoptosis induction. The memantine and sila-421-complexes of amyloid increased apoptosis. Late apoptosis and viability of cells were not changed significantly by memantine and disiloxane-complexes.

The authors suggest that resistance modifiers form complexes with amyloid. The $\mathrm{ABC}$ transporters may have theoretical interest since they are responsible for the functions of barriers in different tissues e.g. BBB, gut, kidney, placenta, testis, liver, adrenal cortex and breast by regulating efflux of endogenous and exogenous substrates including amyloids, hormones and chemotherapeutics. One strategy for reversal of the resistance in tumor cells expressing $\mathrm{ABC}$ transporters is the combination of antitumor chemotherapeutics with resistance modifiers. The clearance of amyloid-beta from the brain represents a therapeutic target for a human brain endothelial cell line hCEMC/D (3). Tai et $a l$. suggested that pgp and BCRP might act to prevent blood borne amyloid-beta from entering the brain (8). Brenn and coworkers had shown that amyloid beta 1-42 itself down regulates the expression of pgp and amyloid beta transporters could enhance the intracerebral accumulation of amyloidbeta. As a consequence, accelerate neurodegeneration in $\mathrm{AD}$ and cerebral beta-amyloid angiopathy in vivo (10).

The two main problems related to chemotherapy of cancer and $\mathrm{AD}$ are theoretically similar. Chemotherapy inefficiency due to drug resistance can be overcome by inhibition of $\mathrm{ABC}$ transporter. In case of cancer, the reversal of drug resistance of tumor cells expressing $\mathrm{ABC}$ transporters by the combination of anticancer drugs and chemosensitizers holds a great promise for improved chemotherapy. However, in AD the reduced clearance across BBB and accumulation of betaamyloid -as a pgp substrate- are responsible for the neurologic dysfunction, that has a key role in the development of beta-amyloid mediated angiopathy. In this case betaamyloid is considered as endogenous substrate, however in 
Table I. MDR reversal in the presence of amyloid complexes.

\begin{tabular}{|c|c|c|c|c|c|c|c|}
\hline & & $\begin{array}{c}\text { Concentration } \\
\mu \mathrm{g} / \mathrm{ml}\end{array}$ & $\begin{array}{c}\text { FSC } \\
\text { Forward scatter count }\end{array}$ & $\begin{array}{c}\text { SSC } \\
\text { Side scatter count }\end{array}$ & $\begin{array}{c}\text { Mean } \\
\text { fluorescence }\end{array}$ & $\begin{array}{l}\text { FAR fluorescence } \\
\text { activity ratio }\end{array}$ & Peak channel \\
\hline 1 & PAR cells treated & - & 2339 & 790 & 111 & - & 96.5 \\
\hline \multirow[t]{2}{*}{2} & PAR cells & & & & & & \\
\hline & Non-treated & - & 2297 & 693 & 105 & - & 93.1 \\
\hline \multirow[t]{2}{*}{3} & MDR & - & 2435 & 965 & 1.48 & - & 1.29 \\
\hline & MDR MEAN & - & 2318 & 942 & 1.13 & - & - \\
\hline 4 & Verapamil & 10 & 2440 & 956 & 3.91 & 3.46 & 2.46 \\
\hline 5 & Memantine hydrochloride & 4 & 2457 & 951 & 1.49 & 1.31 & 1.15 \\
\hline 6 & 40 & 2405 & 950 & 1.84 & 1.62 & 1.43 & \\
\hline 7 & Sila-409 & 4 & 2383 & 999 & 137 & 121.23 & 133 \\
\hline 8 & 40 & 1401 & 1264 & 1.82 & 1.61 & 1.72 & \\
\hline 9 & Sila-421 & 4 & 2324 & 964 & 84.2 & 74.51 & 80.6 \\
\hline 10 & 40 & 1395 & 1320 & 23.8 & 21.06 & 75.0 & \\
\hline 11 & Amyloid $\beta$-protein & 2 & 2388 & 1002 & 1.16 & 1.02 & 1.00 \\
\hline 12 & 20 & 2251 & 967 & 0.846 & 0.74 & 0.806 & \\
\hline 13 & $\begin{array}{l}\text { Memantine hydrochloride } \\
+ \text { Amyloid } \beta \text {-protein }\end{array}$ & $40+2$ & 2358 & 949 & 1.31 & 1.15 & 0.965 \\
\hline 14 & $40+20$ & 2159 & 948 & 1.15 & 1.01 & 0.866 & \\
\hline \multirow[t]{2}{*}{15} & Sila-409 & & & & & & \\
\hline & + Amyloid $\beta$-protein & $40+2$ & 1488 & 1280 & 1.33 & 1.17 & 1.29 \\
\hline 16 & $40+20$ & 1392 & 1164 & 1.20 & 1.06 & 1.04 & \\
\hline \multirow[t]{2}{*}{17} & Sila-421 + & & & & & & \\
\hline & Amyloid $\beta$-protein & $40+2$ & 1392 & 1289 & 1.99 & 1.76 & 1.15 \\
\hline 18 & $40+20$ & 1449 & 1291 & 1.87 & 1.65 & 0.931 & \\
\hline 19 & DMSO & $20 \mu \mathrm{L}$ & 2065 & 944 & 0.810 & 0.71 & 0.698 \\
\hline 20 & MDR & - & 2201 & 919 & 0787 & - & 0.649 \\
\hline
\end{tabular}

Table II. Apoptosis induction in the presence of amyloid complexes.

\begin{tabular}{|c|c|c|c|c|c|c|c|c|}
\hline & MDR & $\mathrm{ml}$ & & & Q1 necrosis & $\begin{array}{l}\text { Q2 late } \\
\text { apoptosis }\end{array}$ & $\begin{array}{l}\text { Q3 early } \\
\text { apoptosis }\end{array}$ & $\begin{array}{c}\text { Q4 viable } \\
\text { non-apoptotic cells }\end{array}$ \\
\hline 1 & Annexin- Propidium iodine- & & & & 0.56 & 0.005 & 0.030 & 99.4 \\
\hline 2 & Annexin ${ }^{-}$Propidium iodine ${ }^{+}$ & & & & 1 & 0.005 & 0.025 & 99.0 \\
\hline 3 & Annexin $^{+}$Propidium iodine ${ }^{-}$ & & & & 0.005 & 0.00 & 2.92 & 97.1 \\
\hline 4 & Annexin $^{+}$Propidium iodine ${ }^{+}$ & & & & 0.716 & 0.686 & 1.78 & 96.8 \\
\hline 5 & DMSO control & $1 \%$ & & & 0.428 & 0.732 & 2.46 & 96.4 \\
\hline 6 & M627 (as positive control in apoptosis) & $50 \mu \mathrm{g} / \mathrm{ml}$ & & & 11.6 & 6.76 & 7.83 & 73.8 \\
\hline 7 & Memantine & $4 \mu \mathrm{g} / \mathrm{ml}$ & & & 0.648 & 0.663 & 1.92 & 96.8 \\
\hline 8 & Sila-409 & $4 \mu \mathrm{g} / \mathrm{ml}$ & & & 0.667 & 0.717 & 2.82 & 95.8 \\
\hline 9 & Sila-421 & $4 \mu \mathrm{g} / \mathrm{ml}$ & & & 1.34 & 0.762 & 3.91 & 94.0 \\
\hline 10 & Amyloid $\beta$ & $4 \mu \mathrm{g} / \mathrm{ml}$ & & & 0.588 & 0.658 & 2.60 & 96.2 \\
\hline 11 & Memantine & Amyloid $\beta$ & $4 \mu \mathrm{g} / \mathrm{ml}$ & $4 \mu \mathrm{g} / \mathrm{ml}$ & 1.21 & 0.935 & 2.60 & 95.3 \\
\hline 12 & Sila-409 & Amyloid $\beta$ & $4 \mu \mathrm{g} / \mathrm{ml}$ & $4 \mu \mathrm{g} / \mathrm{ml}$ & 0.952 & 0.768 & 2.60 & 95.7 \\
\hline 13 & Sila-421 & Amyloid $\beta$ & $4 \mu \mathrm{g} / \mathrm{ml}$ & $4 \mu \mathrm{g} / \mathrm{ml}$ & 2.75 & 0.987 & 5.58 & 90.7 \\
\hline
\end{tabular}

cancer the anthracyclines are exogenous substrates. Consequently, simultaneous administration of resistance modifiers to block the membrane transporter can improve the effectiveness chemotherapy both in cancer and in AD. The reversal of MDR and induction of apoptosis might offer a potential benefit in cancer. We suppose that a synergistic combination between some resistance modifiers e.g. memantine or sila compounds with amyloid-beta may offer further opportunities for chemotherapy of cancer and AD.

Behrens (3) had shown an inverse association between AD and cancer. The question arises: what is the possible common factor in $\mathrm{AD}$ and cancer. Nevertheless, a 
considerable attention has been given to the mechanisms by which amyloid-beta might be transported between the brain and blood and evidence suggests that MDR pgp plays a role in amyloid-beta transport (11), The conclusion of this publication emphasizes that treatments currently under investigation to prevent or to treat AD might lead to a greater risk of cancer development, and inversely, treatments to halt cancer, could predispose to development of $\mathrm{AD}(6,7)$. In cancer, cell regulation mechanisms are disrupted with augmentation of cell survival and proliferation, whereas conversely AD is associated with increased neuronal death, either caused by concomitant beta-amyloid complexes and tau deposition. Association between cancer and AD is made more imperative considering that treatments currently under investigation to prevent, and treat $\mathrm{AD}$, might lead to a greater risk of cancer development $(7,8)$.

Significantly lower expression of ABC transporters was found following expression of amyloid-beta 1-42, but not its scrambled or complexed equivalent (12). In our experiments the two studied disiloxanes had shown some chemopreventive effects in vivo (13). Similar effect was found also in vivo in human pancreatic cancer xenograft-inoculated mice (14). In addition to the beneficial effects of the sila-409 and sila-421 on chemoprevention, the identified vascular activity of the two compounds can be promising for further in vivo studies (model experiments) in rational drug design (15).

\section{Acknowledgements}

The Authors would like to express sincere gratitude for the assistance to Aniko Vigyikán. This study was supported by Szeged Foundation for Cancer Research and GINOP 2.3.2-15-2016-00038. University of Szeged, Hungary.

\section{References}

1 Molnar J, Szabo D, Mándi Y, Mucsi I, Fisher J, Varga A, Köning $\mathrm{S}$ and Motohashi N: Multidrug resistance reversal in mouse lymphoma cells by heterocylic compounds. Anticancer Res 18 : 3033-3038, 1998.

2 Fakla A, Hevér A, Molnár J and Fisher J: Tomato lectin labels the $180 \mathrm{kD}$ glycoform of p-glycoprotein in brain capillary endothelia and mdr tumor cells. Anticancer Res 18: 3107-3112, 1998.

3 Behrens MI, Lendon C and Roe CM: A common biological mechanism in cancer and Alzheimer's Disease. Curr Alzheimer Res 6(3): 196-204, 2009.

4 Dao P, Ye F, Liu Y, Du ZY, Zhang K, Dong CZ, Meunier B and Chen H: Development of phenothiazine-based theranostic compounds that act both as inhibitors of $\beta$-amyloid aggregation and as imaging probes for amyloid plaques in Alzheimer's disease. ACS Chem Neurosci 8(4): 798-806, 2017.
5 Hegyes P, Molnar J, Mucsi I, Hevér A, Szabo D, Kiessig ST, Lage H, Gaal D and Nacsa J: Substituted disiloxanes method for production thereof and the use thereof for reversal of multidrug resistance (MDR) (PCT/DE00/04110,2000, and Molnar J: European Patent No, Patent haber 1432717, 01.03.06, München.

6 Molnar J, Mucsi I, Nacsa J, Hevér A, Gyémánt N, Ugocsai K, Hegyes P, Kiessig ST, Gaál D, Lage H and Varga A: New silicon compounds as resistance modifiers against multidrug resistant cancer cells, Anticancer Res 24(4C): 665-872, 2004.

7 Kimura M, Komatsu H, Ogura $\mathrm{H}$ and Sawada K: Comparison of donepezil and memantine for protective effect against amyloidbeta (1-42) toxicity in rat septal neurons. Neurosci Lett 391(12): 17-21, 2005.

8 Tai L, Louglhin AJ, Male DK and Romero IA: P-glycoprotein and breast cancer resistance protein restrict apical-to-basolateral permeability of human brain endothelium to amyloid beta. $\mathbf{J}$ Cerebral Blood Flow Metabo 29(6): 1079-1083, 2009.

9 Kuhnke D, Jedlitschky G, Grube M, Krohn M, Jucker M, Mosyagin I, Cascorbi, Walker LC, Kroemer HK, Warzok RW and Vogelgesang SL: MDR1-P-Glycoprotein (ABC1) mediates transport of Alzheimer's amyloid beta peptides - implications for the mechanisms of A-beta amyloid clearance at the bood brain barrier. Brain Pathol 17(4): 347-353, 2007.

10 Brenn A, Grube M, Peters M, Fischer A, Jedlitschky G, Kroemer HK, Warzok RW and Wogelgeshang S: Beta-amyloid down regulates MDR1-P-glycoprotein (Abcb1) expression at the blood brain barrier in mice. Int J Alzheimer's Dis 2011: 690121, 2011.

11 Wei W, Bodles-Brakhop AM and Barger SW: A role for pglycoproten in clearance of Alzheimer amyloid beta peptide from the brain. Curr Alzheimer Res 13(6): 615-630, 2016.

12 Kania KD,Wijesuriya HC, Hladky TB and Barrand MB: Beta amyloid effects on expression of multidrug efflux transporters in brain endothelial cells. Brain Res 1418: 1-11, 2011.

13 Tokuda H, Maoka T, Suzuiki N, Hohmann J, Vasas A, Engi H, Mucsi I, Olszewski U, Hamilton G, Amaral L and Molnar J: Effects of two disiloxanes ALIS-409 and ALIS-421 on chemoprevention in model experiments. Anticancer Res 33(5): 2021-2028, 2013.

14 Zalatnai A and Molnár J: Effect of SILA-409, a new organosilicon multidrug resistance modifier on human pancreatic cancer xenografts. In Vivo 20(1): 137-140, 2006.

15 Fusi F, Ferrara A, Zalatnai A, Molnar J, Sgaragli G and Saponara S: Vascular activity of two silicon compounds, alis 409 and alis 421 , novel multidrug-resistance reverting agents in cancer cells. Cancer Chemother Pharmacol 61(3): 443-451, 2008. 